\title{
Making a Low Risk Kampong to Urban Fire
}

\author{
Adjie Pamungkas ${ }^{*}$, Dian Rahmawati, Kesumaning Dyah Larasati, Gusti Aditya Rahadyan and Abdiel \\ Hardwin Dito \\ Institut Teknologi Sepuluh Nopember Surabaya \\ Indonesia \\ Corresponding author's email: adjie.difi [AT] gmail.com
}

\begin{abstract}
Urban fire in Surabaya has made 36 fatalities with IDR 97.9 Billion losses in the last five years since 2015. Nyamplungan, one of the neighborhood units in Ampel Precinct, has been dominated with medium level of social and physical vulnerabilities with a low level of capacity. Those risk characteristics in Nyamplungan and its status as cultural-heritage site of Surabaya make that the risk management based on communities in the area is an urgent step to enhance community resilient. These serial participatory action researches have increased community knowledge on risk management, identified historical fire incidents, formed a community group in responding to potential fire hazards, valued the risk level with medium level domination, identified emergency infrastructures, agreed on three main scenarios of future disaster scale, designed action plans from 8 key stakeholders in emergency responses and made six alternatives on evacuation routes.
\end{abstract}

Keywords- risk, kampong, urban fire, participatory action research.

\section{INTRODUCTION}

Historically, Kampong in Surabaya is stated as the urban heritage (Surabaya Regional Spatial Plan, 2014). It preserves historical sites and cultural values for Surabaya. Nyamplungan Neighbourhood Unit, Ampel Precinct-Pabean Cantikan Regency is one of the kampongs heritages. Ampel is a centre for Islamic activities since the $15^{\text {th }}$ Century started by Sunan Ampel. From Ampel Mosque, the sunan (Islamic priest) preach Islam to the surrounding areas including other municipalities such as Gresik, Sidoarjo and Pasuruan. Today, Ampel, particularly Ampel Mosque, is one of the tourist destinations for religious attractions. The multipliers on the tourism related to religious activities make the precinct as one of the key sites for trading related to worshipping equipment in the city scale. Furthermore, the surrounding communities near Ampel Mosque have been part of the old town communities in Surabaya. Community from Arabic descendant in the precinct highlight the importance of the sites both for historical and cultural aspects of the community. Moreover, particularly in Kembang Jepun Road, the city government programs such as kya-kya program promote a china town developed area. Therefore, the precinct is a well-known area as the religious, trading centre and community acculturation between Arabic, Chinese descendants, the local Javanese and Madurese tribes.

The old town of Surabaya is still holding significant role in regional trading of Indonesia particularly the eastern part of Indonesia. Tanjung Perak Port has served 32 domestic routes from and to Surabaya (Lestari, 2015). The port activities have been the engine of Surabaya economic growth up to now. The port's multiplier effects have also been accommodated in the area of Surabaya old town as a Surabaya CBD (central business district). The CBD has been contributing to the steady economic growth of Surabaya with 7\% of GDP growth.

As part of the old-town communities and kampongs, the precinct is a densely populated area. The row houses dominate the areas with no gap between one house to another. The functions of houses are also a mix between residential, warehouses and commercial areas. Most of the houses in the main access to the mosques have two functions both as residential and commercial use. A narrow alley becomes the main road to access this type of kampong. Surabaya Medium Term of Development Program 2010-2015 indicates the precinct as one of the vulnerable areas to urban fire. In Surabaya city scale, the highest fire incidents in last 5 years were in 2015 with 609 incidents. The Surabaya Fire Incidents Recapitulation from 2011 up to 2015 indicates the increasing pattern of fire incidents (Figure 1). 


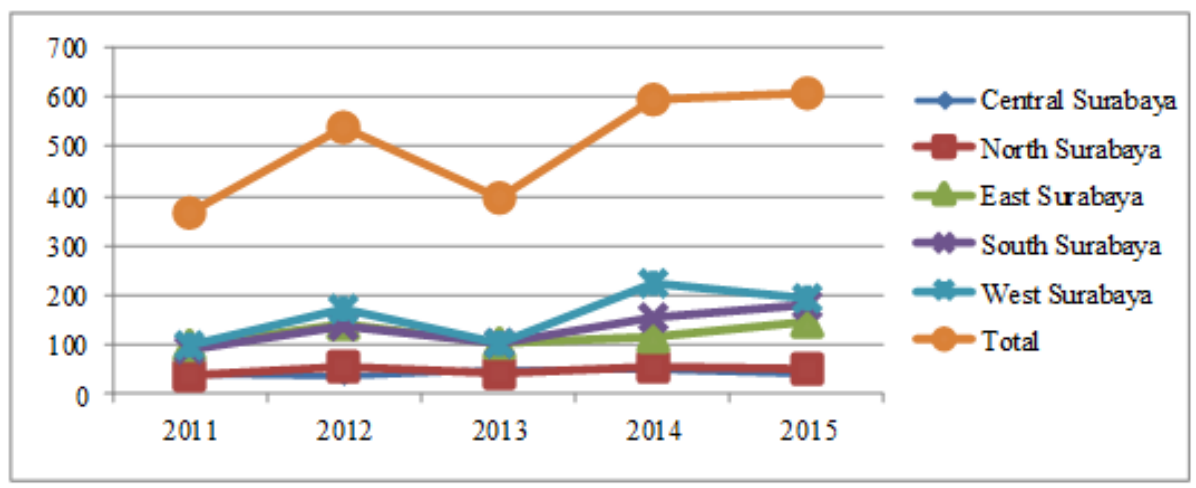

Figure 1: Number of fire incidents in Surabaya

Based on Surabaya Regional Legislation on 2004, the fire incidents are majority caused by low degree of understanding from community on fire hazard, unprepared responses to the fire incident and hardly accessible areas for fire engines. Furthermore, In the mid of March 2015, again, the Surabaya Mayor refused to form regional disaster board (Baktiono, 2013) indicating the low understanding on building urban resilience. Coordination Unit of Disaster Management is in place for the current responsible government body in Surabaya. This organisation has been notified as reactive action (Pamungkas, 2013).

Therefore, building low risk kampong to urban fire in Nyamplungan is an urgent step to enhance community resilience. Building low risk kampong will include community organisation, participatory contingency plan and evacuation routes. Those actions are a combine instruments both from bottom up and top down measures in disaster risk management.

\section{METHODS}

In responding to the situation above, a combine study and stakeholders empowerment on building low risk kampong to urban fire can decrease the economic impact of urban fire and preserve the historical built environment as well as cultural values in the Surabaya heritage area. Building low risk kampong can minimise the risk as well as build stronger community in the future. This combine study and stakeholders empowerment is a participatory action research (PAR) method to find the best solution for the community as well as the city manager. Participatory action research (PAR) is an approach to research in communities that emphasizes participation and action (Chevalier and Buckles, 2013). It seeks to understand the world by trying to change it, collaboratively and following reflection. PAR emphasizes collective inquiry and experimentation grounded in experience and social history. Selected stakeholders are involved in this serial study including from government, private sectors and civil society.

\section{RESULTS AND DISCUSSION}

The idea of making a low risk kampong is begun with a community capacity building to enhance community understanding on building resilience to urban fire. The next stage is risk mapping to identify the level of risk to urban fire in Nyamplungan Precinct. Risk mapping will include the assessment on urban fire as the key hazard, community vulnerability and community capacity. Having the risk assessment, we continue the idea of making a low risk kampong to make its contingency planning and building guidelines. Furthermore, the contingency planning will focus on how the communities can immediately response to the future fire incident. In contingency plan, we propose an evacuation plan consisting alternative routes for emergency response.

\subsection{Community Capacity Building}

In community capacity building, there are 6 key steps to ensure the risk management in Nyamplungan effectively reducing the impact of urban fire. The six key steps are building trustworthiness, brainstorming on urban fire risk, community hazard mapping, discussion on hazard mapping, making a mitigation plan via participatory planning and community organization. We involve 22 key stakeholders including the leaders of sub-neighborhood unit (RT), the leaders of neighborhood unit (RW), Kampong representative board (LKMK), the leader of family welfare Program at kampong level (PKK) and the leader of regency (lurah). In terms of ethnic, the multiethnic are involved in this capacity building including Javanese, Madurese and Arabian descendent.

After the key steps are conducted in building community capacity building on urban fire risk management, we can conclude several improvements on community such as;

1. Community knowledge on the basic understanding of fire is increase from $60 \%$ to $85 \%$. The basic understanding includes the risk of urban fire in Nyamplungan Precinct due to densely populated areas, 
community ignorance, high-risk activities to fire incidents, building material prone to fire and high-risk characteristic of residential area to fire.

2. After hazard mapping, community understand fully on the high potential hazards in surrounding areas. It is completely different from before hazards mapping. Before the hazard mapping, communities have very limited understanding on urban fire characteristics. Figure 2 identifies the potential fire risk (hazard mapping) in Nyamplungan Precinct based on community perspective.
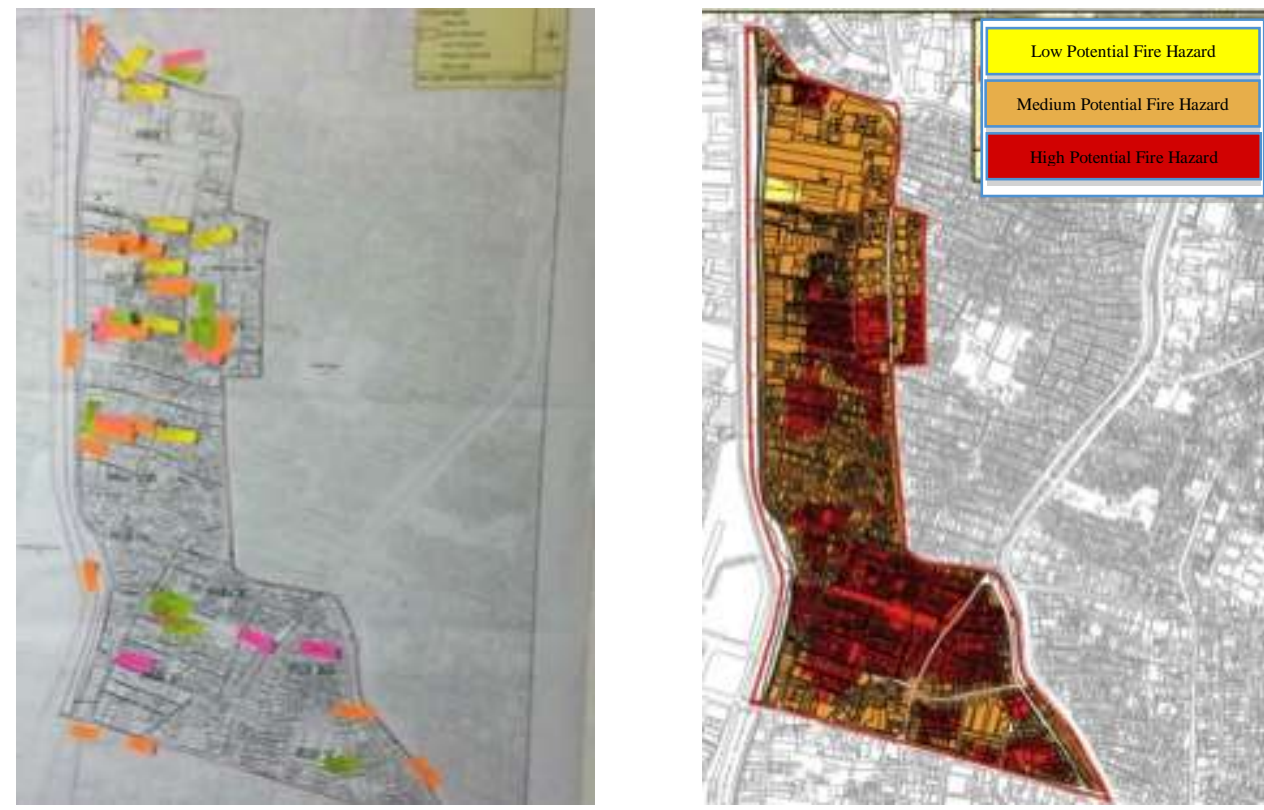

Figure 2: Fire Hazard Mapping Based on Community Perspective

The community hazard mapping has two fold benefits for the community. The first one is enhancing the understanding of fire incidents surrounding their areas. And the second one is making a written document with spatial perspective at community level on the fire incidents. A written document is needed since there is no official document for fire incident at the precinct level in Nyamplungan. Since the first map produced by community is then discussed in FGD (focus group discussion) format, the FGD can enhance community awareness and understanding on urban fire risk. Therefore, this method is very important in CBDRM (community based disaster risk management) process.

3. Community awareness has been increases from no action to minimize the high potential fire hazards to agreed actions for future fire incidents. Community propose several key mitigation measures for future hazards, that are:

a. Community has abilities to extinguish the fire incident with both traditional and special extinguisher.
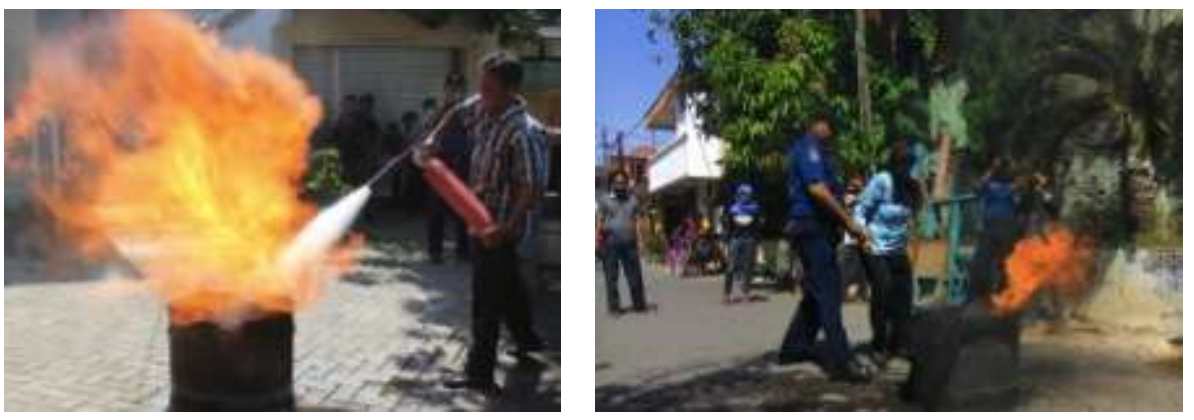

Figure 3: Community Training on Extinguishing Potential Fire both with Traditional and Special Extinguisher

b. Building community readiness via providing the fire brigade phone number for every house, electricity maintenance to avoid short-circuiting and providing an adequate extinguisher for neighborhood level.

4. Sustainability program on urban fire risk management is also improved after the capacity building program. The community has formed a special task force for urban fire called by FBI (Fire Brigade Inspector). The FBI has a duty to implement the community plan as on Figure 4. Furthermore, the FBI also connect to the fire 
volunteering program which is part of the Surabaya Fire Brigade Unit. Therefore, the FBI has a good networking in implementing its program.
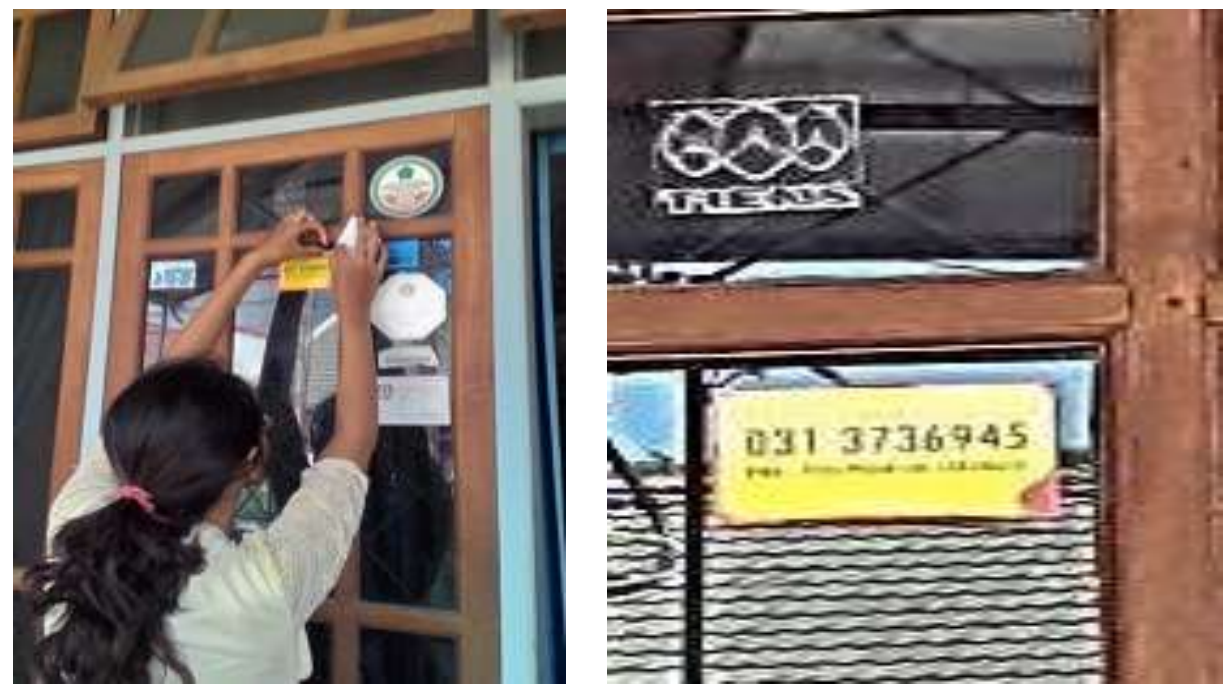

Figure 4: Initial Actions for Providing Fire Brigade Phone Number in Every House in Nyamplungan

\subsection{Urban Fire Risk Mapping}

A risk assessment is a process of combining the assessment outputs on hazards, vulnerability and capacity (BNPB Regulation No. 02/2012). A thorough explanation on urban fire risk mapping in Nyamplungan has been discussed in Rahmawati et al., 2016; Rahmawati et.al., 2015. For hazard assessment, we include the frequency, economic losses, number of fatalities and number of people with burns injury as key criteria of the assessment. In terms of vulnerability, we calculate with three kinds of vulnerability that are social, economic and physical vulnerabilities (Pamungkas, 2013). Selected variables for those three kinds of vulnerabilities are:

1. Social vulnerability with variables of population density, sex ratio, disables ratio and age group.

2. Economic vulnerability includes variables of areas productivity that is reflected by land use type.

3. Physical vulnerability has variables of building density, land use type and emergency facilities availability.
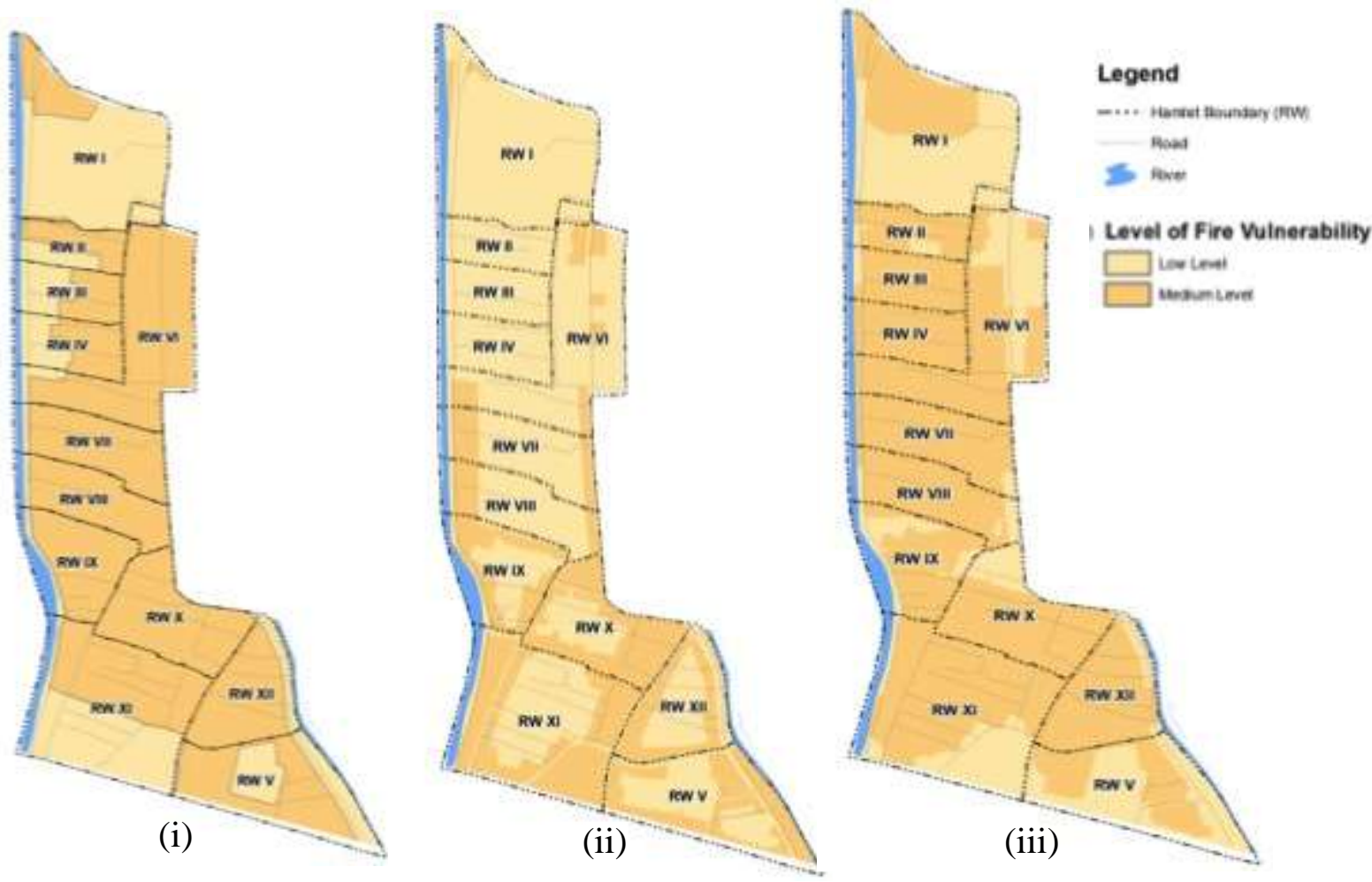

Figure 5: The Output of Social (i), Economic (ii) and Physical (iii) Vulnerability 
Furthermore, community capacity level is valued from participatory hazard mapping process and observation on emergency facilities availability in their community. From those two types data; we value community awareness variables.

Having hazard assessment, we can see that most of the high potential hazard is in the neighborhood unit (RW) of III, VI, IV, VII and VIII. In addition, RW II has partially high potential fire hazards and other part of RW II has medium level of hazard. The high potential hazard map has different from a participatory hazard mapping in point A since the participatory hazard mapping only map the distribution of fire incidents. Most of the areas with high potential hazard have frequent fire incidents and also significant impacts to the community.

Other part of them, we value the areas as medium potential hazard level. Eventhough RW I, X and XI has high potential hazard based on participatory hazard mapping, we still value both RWs are in medium level since the fire incidents have limited impacts to the community. Figure 6 illustrates the output of hazard mapping.

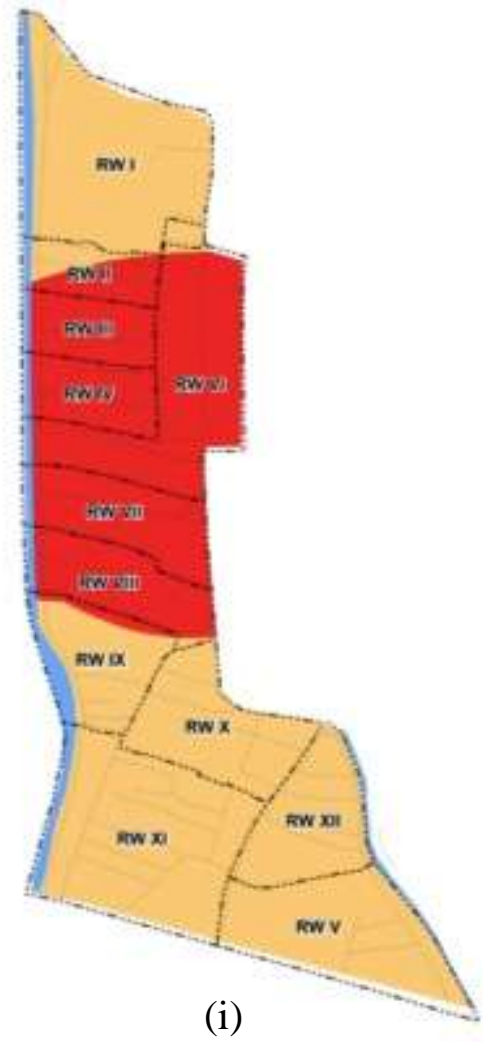

(i)

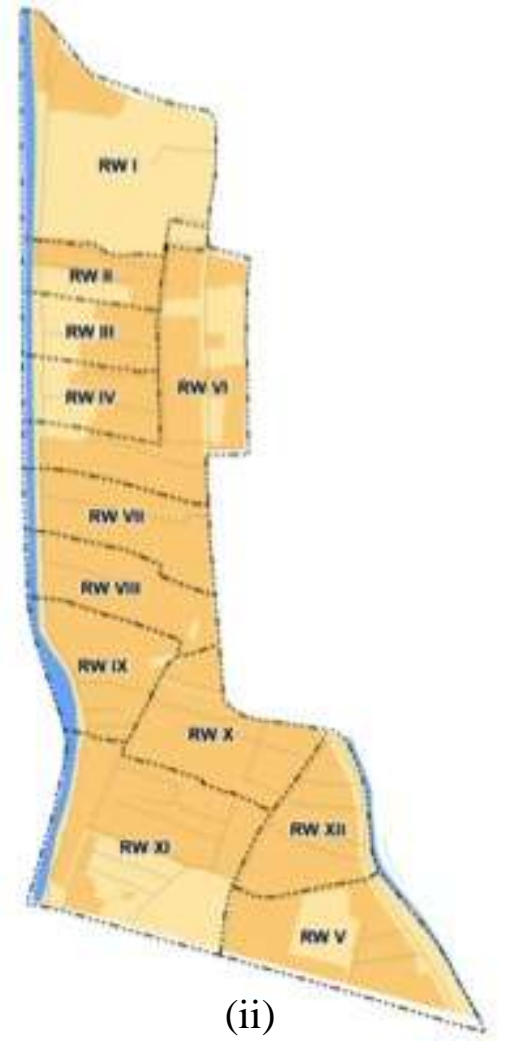

(ii)

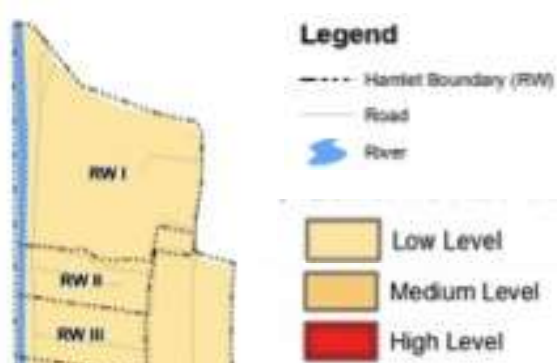

(iii)

Figure 6: The Output of Hazard (i), Vulnerability (ii) and Capacity (iii) Assessment

In terms of vulnerability, most of the area in Nyamplungan Precinct has medium level of vulnerability. Physical vulnerability has dominated the judgment on community vulnerability level. From all the variables, building density, land use type and emergency facilities availability are critical variable in assessing community vulnerability.

For the capacity, most of the areas are in low level of capacity. Most of the residents have limited knowledge on fire risk and adaptation to the fire incident. It can be seen from the output pre test in the beginning of capacity building program. Only community along the Kembang Jepun Corridor has medium level of capacity since they are more aware than the rest of communities in Nyamplungan. From the observation, we can also find out that light extinguisher has already supported the corridor. The awareness is increases in the corridor because most of the areas in the corridor are commercial areas with higher level of financial ability than the rest of communities. Therefore the residents has internal motive not only to protect their own consumptive assets but also their productive assets.

Having the hazard, vulnerability and capacity assessment, we overlay those three outputs to have urban fire risk map. Most of the areas are in medium level of risk. Only RW I has a dominated area with low risk level. The spot in RW I is actually a warehouse with as full equipped means of fire response and low density. RW XI has around equal portion between low and medium level of urban fire risk. The medium risk level in RW XI is indicated by the low level of social vulnerability (caused by low population density) and low level of physical vulnerability (caused by low building density). Furthermore, some areas in medium level risk for RW XI are in commercial strips of Kembang Jepun with medium level of capacity. 


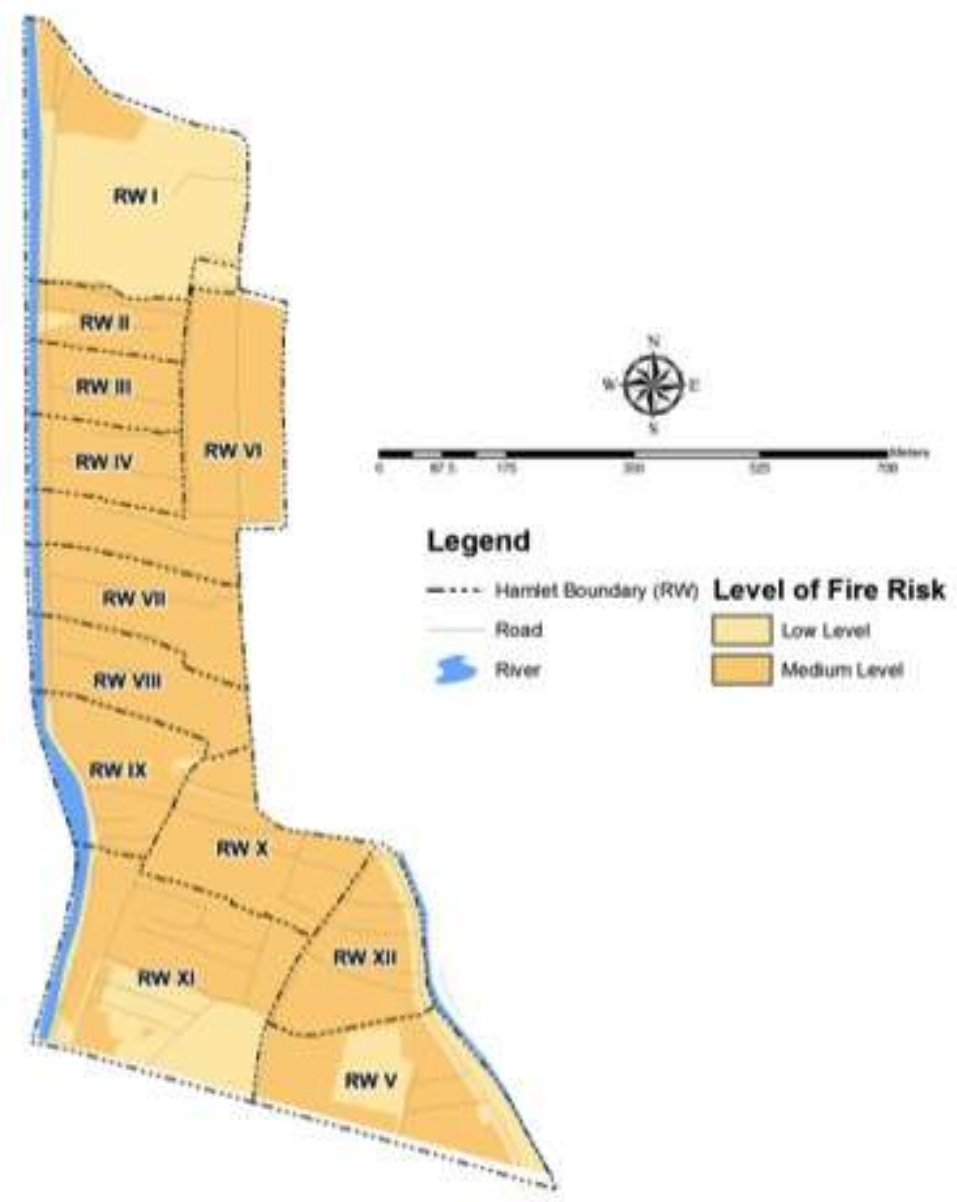

Figure 7: Urban Fire Risk Map

\subsection{Contingency Planning}

Contingency plan is a preparation plan for immediate response to disaster. In contingency plan, we define the scenario of possible disaster; possible resources for immediate response; and actions plan for effective immediate response. FGD is used to discuss those three key outputs. FGD can also build a commitment among stakeholders particularly in implementing the contingency plan.

For the fire scenario, the community has defined 3 types of fire, which are small, medium and large fire incidents. For the small-scale fire incident, the burnt houses could be around 1 or 2 houses, in which community can extinguish the fire without any assistant from fire brigade. In medium-scale fire incident, the burnt houses could be more than 2 houses up to five houses, in which community need assistant from local fire brigade. And, the large-scale fire incident covers a block of the precinct which involves a city scale of fire brigade.

In terms of possible resources for immediate response, we have identified four main possible resources that are; open space, water supply, emergency facilities and loudspeaker (Figure 8). The open space is useful to minimize the risk of fire spreading to surrounding buildings. The community can also use open space as a temporary evacuation area in emergency situation. Since Nyamplungan is a densely populated area, only 5 locations are identified as useful open space for fire risk management. Water supply is needed to extinguish the fire. The supply can be from the fire trucks, river, well, inhabitants' water storage and drainage. Beside water, other facilities relevant to fire risk management are hydrant and traditional or non-traditional fire extinguisher. The non-traditional fire extinguisher (a carbon dioxide extinguisher) is filled with non-flammable carbon dioxide gas under extreme pressure. The traditional one is usually a wet burlap sacks, a bucket of sand or other effective tools. In FGD, we identify a need on carbon dioxide extinguisher since the traditional one can be provided at every house by the communities. A loudspeaker is useful to spreading the information on fire incidents. Only mosque has a proper loudspeaker in Nyamplungan. 


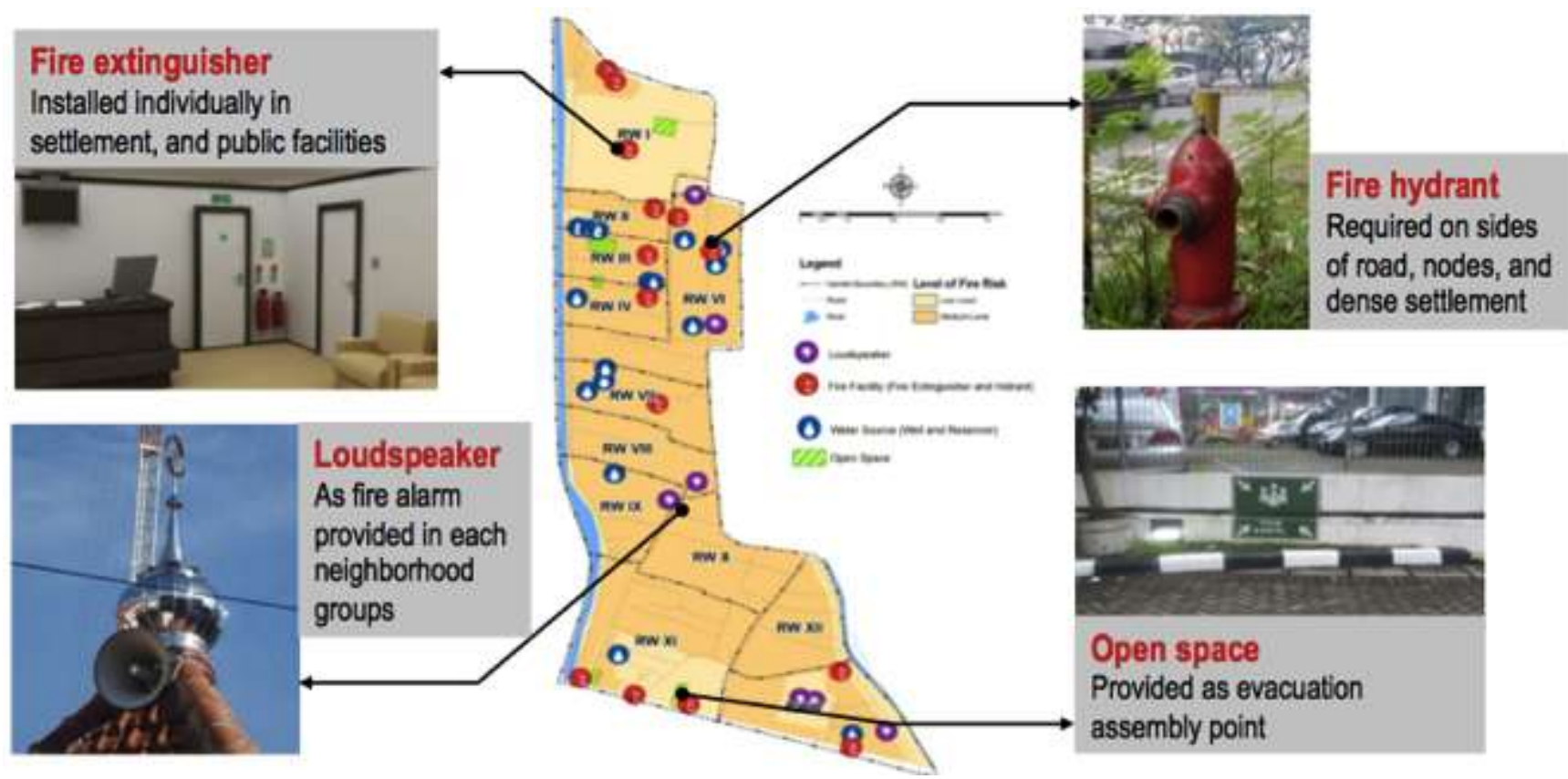

Figure 8: The Location on Possible Resources for Immediate Response

To have effective actions plan in emergency situation, we identify eight key groups of actors for emergency response that are head of regency, Nyamplungan disaster response unit, nearest hospital, Fire brigade agency, planning and development board, RT and RW leaders, police department and local informal leaders. All the actors are then have their own roles in certain sector. We classify the actions into six sectors that are; sector of management and coordination; health; evacuation and protection; transportation; logistics and infrastructures.

Specifically for the evacuation, we propose an evacuation route after considering risk maps and the location on possible resources for immediate response.

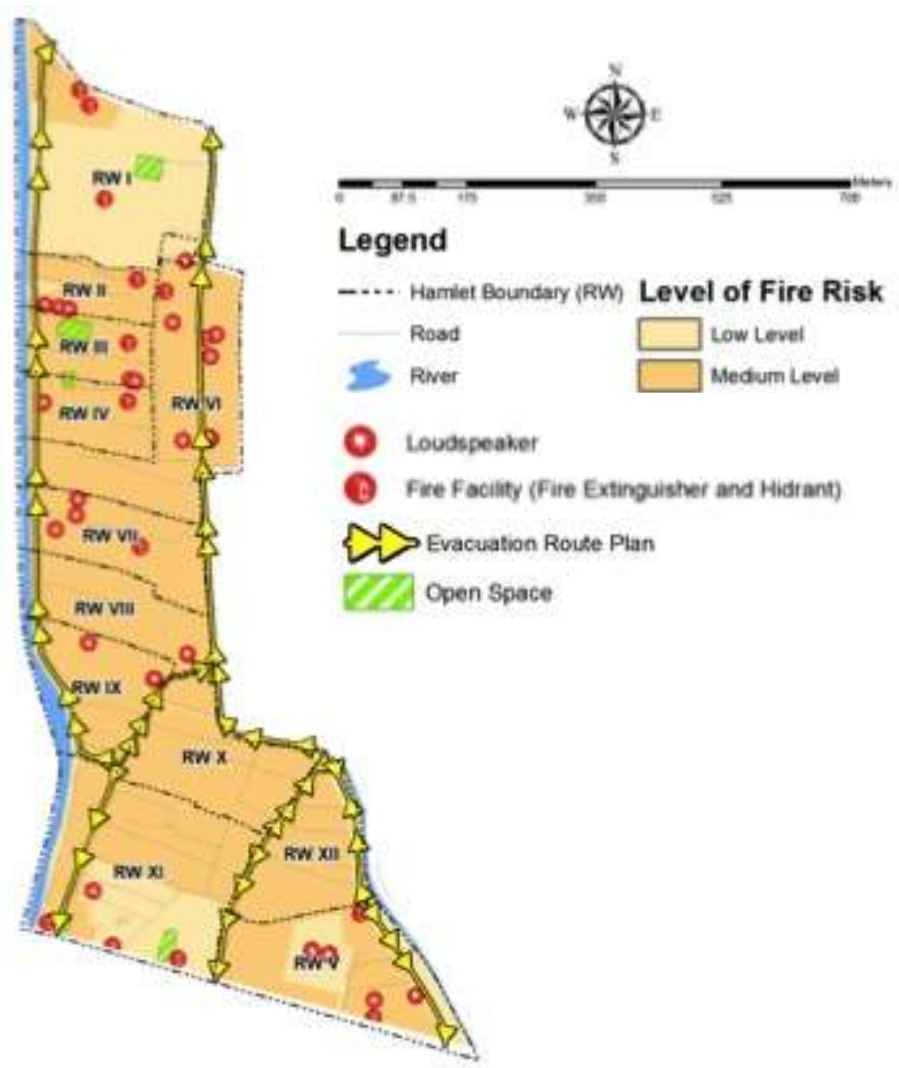

Figure 9: The Alternatives Evacuation Routes 
Specifically for the evacuation, we propose an evacuation route after considering risk maps and the location on possible resources for immediate response. Figure 9 illustrates six alternatives evacuation routes that are;

1. Route passing Kalimas Timur Rd. to the north via Benteng Rd. and Indrapura Rd.

2. Routes passing Kalimas Timur Rd. to the south via Kembang Jepun Rd.

3. Route passing KH. Mas Mansyur Rd. to the north via Benteng Rd and Sultan Iskandar Muda Rd.

4. Route passing Dukuh Rd. to the south via Kembang Jepun Rd.

5. Route passing Panggung Rd. to the south via Kembang Jepun Rd.

6. Route passing Songoyudan Rd. to the south via Kembang Jepung Rd.

Every neighborhood lane leads to evacuation site through evacuation routes.

\section{CONCLUSION}

In making a low risk kampong to urban fire, capacity building is the beginning step to enhance community awareness on the risk. Two ways communication such as FGD and training can increase community understanding as well as their skills. The FGD also encourage the community to be involved in designing the risk management such as risk mapping, resources identification up to making an evacuation plan. Therefore, the output of making a low risk kampong (such as FBI, risk maps and evacuation plan) is as important as the making process (training and FGD).

In terms of the output, in building capacity, a two ways communication via FGD and training is effectively increasing the community capacity. Moreover, this empowering mode can also provide basis data for further risk management and planning. For risk assessment, the low capacity raises the need of community preparedness program. A collaborative planning on contingency plan results agreeing on three scales of disaster scenarios and their arrangements on key actors based on the scales, defining possible existing resources/tools for emergency response (such as mosques' loudspeakers, green open space, etc), additional resources/tools for emergency response (such as providing a carbon dioxide extinguisher in every RT and wet burlap sacks in every house) and making an evacuation route in which heading to the outer edges of the kampong since the roads are wider compared to road in the inner areas.

\section{ACKNOWLEDGEMENT}

The article is a summary of various steps of research and outreach programs funded by Institut Teknologi Sepuluh Nopember. We thank to our colleagues for full support related with preparation and finishing this paper.

\section{REFERENCES}

[1] Badan Nasional Penanggulangan Bencana (BNPB - National Board for Disaster Management), Peraturan Kepala Badan Nasional Penganggulangan Bencana (BNPB) No. 02 Tahun 2012: Pedoman Umum Pengkajian Risiko Bencana (Guidelines for Disaster Risk Assessment), 2012.

[2] Baktiono, Risma itu angkuh dan sombong (Risma (the city mayor) is supercilious and arrogant), Surabaya Pagi $\begin{array}{lllll}\text { Newspaper, } & \text { retrieved } & \text { January } & 20 & \text { th, }\end{array}$ http://surabayapagi.com/index.php?3b1ca0a43b79bdfd9f9305b812982962464464b345bd4246d1458394da6c88c9, 2013.

[3] Chevalier, J.M. and Buckles, D.J., Participatory Action Research: Theory and Methods for Engaged Inquiry, Routledge UK. ISBN 978-0415540315., 2013.

[4] Chumaidah, N., Kepala Pemadam Pingsan, Walikota Risma Ambil Alih (The Head of Fire Brigade is unconscious, The City Mayor take over (the leadership)), Tempo.com, Retrieved $7^{\text {th }}$, 2015 from https://m.tempo.co/read/news/2013/11/04/058526987/kepala-pemadam-pingsan-wali-kota-risma-ambil-alih, 2013

[5] Lestari, S.H. Rute Pelayaran Bertambah, Dukung Peningkatan Arus Peti Kemas (More Routes on cruise support the container shipping), Tribunnews.com, $\quad$ Retrieved $\quad 7^{\text {th }}, \quad 2015 \quad$ from http://www.tribunnews.com/regional/2015/01/07/rute-pelayaran-bertambah-dukung-peningkatan-arus-petikemas, 2015.

[6] Pamungkas, A., Vulnerability Assessment for Disaster Risk Management: A Case Study of Floods in Centini Village, Indonesia, RMIT University, 2013.

[7] Rahmawati, D., Pamungkas, A., Aulia B.U., Larasati K.D., Rahadyan, G.A., and Dito, A.H., Participatory Mapping for Urban Fire Risk Reduction in High Density Urban Settlement. Proceeding of Cities 2015, International Conference, Intelligent Planning Toward Smart Cities, Procedia - Social and Behavioral Sciences, Vol. 227, pp. 395-401, 2015

[8] Rahmawati, D., Pamungkas, A., Larasati K.D., Rahadyan, G.A., and Dito, A.H., Participatory Mapping Implementation in Capacity Building of Urban Fire Risk. Asian Journal of Applied Sciences, ISSN: 2321 - 0893 Vol. 04, pp. 1079-1085, 2016.

[9] Surabaya Fire Incidents Recapitulation, Data Kejadian Kebakaran Kota Surabaya, Surabaya Fire Department, 2016.

[10] Surabaya Municipal Government, Surabaya Medium Term of Development Program 2010-2015. Surabaya: Surabaya Municipality, 2010. 
[11] Surabaya Regional Spatial Plan, Peraturan Daerah Kota Surabaya No. 12 tahun 2014 tentang Rencana Tata Ruang Wilayah Kota Surabaya 2014-2034 (Surabaya Legislation Act No. 12/2014 on Regional Spatial Plan 2014-2034), Surabaya's House of Representative, 2014. 